\title{
Peertechz
}

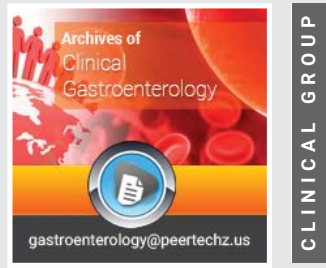

\section{Continue peritoneal lavage in acute pancreatitis: How do peritoneal cells response?}

\author{
Mariana Barreto Serra*, Denise Frediani Barbeiro, Heraldo \\ Possolo de Souza and Marcel Cerqueira César Machado
}

Received: 09 April, 2021

Accepted: 09 June, 2021

Published: 10 June, 2021

*Corresponding author: Mariana Barreto Serra, Clinical Medicine Department, Medical School, Emergency Medicine Laboratory (LIM-51), University of São Paulo, Av. Dr. Arnaldo, 455, São Paulo, SP, 01246-903, Brazil, Tel: +55113061-7000; E-mail: maribserra@usp.br

Keywords: Acute pancreatitis; "Step up approach" Peritoneal cells; Peritoneal cavity; Peritoneal lavage

https://www.peertechzpublications.com

Check for updates

Clinical Medicine Department, Medical School, Emergency Medicine Laboratory (LIM-51), University of

São Paulo, Av. Dr. Arnaldo, 455, São Paulo, SP, 01246-903, Brazil

\section{Abstract}

Continuous peritoneal lavage is part of a set of minimally invasive techniques, called the Step up approach. These techniques have been used in the management of acute necrotizing (severe) pancreatitis (SAP), as they remove toxins and reduce serious metabolic disorders, although their effects on mild acute pancreatitis and on the content of peritoneal cells during mild and SAP are still unknown, since inflammation is an important factor in the progression of the disease. The peritoneum is a tissue with important immunological functions, and the characterization of peritoneal cells during acute pancreatitis can be a relevant strategy to understand the mechanism by which peritoneal lavage has worked during clinical practice, as well as to uncover possible pharmacological targets. This review presents an approach to minimally invasive techniques in the management of AP, emphasizing peritoneal lavage and its nuances.

\section{Introduction}

In most cases of Acute Pancreatitis (AP) the disease has a moderate course, where moderate fluid resuscitation, pain control, nausea and early oral feeding result in rapid clinical improvement [1]. A systematic review by Xiao, et al. (2016) addressed epidemiological data related to the global prevalence of AP, bringing together high-quality studies specifically population-based cohort studies carried out in populations in general. This article reported that the global incidence of acute pancreatitis is 34 cases ( $95 \%$ confidence interval (CI) 23-49) per 100,000 inhabitants in general per year, with no statistically significant difference between men and women. The combined mortality of an episode of acute pancreatitis in seven population-based cohort studies evaluated in the systematic review by Xiao, et al. was 1.16 (95\% Cl $0.85-1.58)$ per 100,000 general inhabitants per year [2].

The evaluation of patients with AP is complex, as it is a disease that has variable etiology, clinical presentation, anatomopathological aspect and treatment [3]. The most serious cases, which comprise about 20 to $30 \%$ of patients, represent a high risk of life, with hospital mortality rates of around 15\% [4]; other complications of include systemic inflammatory response syndrome (SIRS), acute respiratory distress syndrome (ARDS) and sepsis [5].

The most widely used classification for acute pancreatitis is based on the 2012 revision of the Atlanta classification and definitions resulting from international consensus [6]. This classification system identifies two stages of the disease: early and late. As for severity, it can be classified as mild, moderate or severe. The mild form (interstitial edematous pancreatitis) does not show organ failure, local or systemic complications and usually resolves within the first week. If there is transient organ failure (less than $48 \mathrm{~h}$ ), local complications or exacerbation of the comorbid disease, it is classified as moderate. Patients with persistent organ failure (more than $48 \mathrm{~h}$ ) have the severe form of the disease [6].

Around 20 to $40 \%$ of patients with severe acute pancreatitis have infection of pancreatic and peripancreatic necrosis, which is considered to have a poor prognosis because it is responsible 
for the worsening of organic functions. In a systematic and meta-analysis review, totaling 6970 patients, the mortality rate in patients with necrosis and organ failure was $35.2 \%$, while concomitant sterile necrosis and organ failure were associated with a mortality of $19,8 \%$. If patients had infected necrosis without organ failure, mortality would be $1.4 \%$ [7].

Currently, several trends in the management of SAP have changed clinical practices; early enteral feeding, selective role of prophylactic antibiotics, avoiding surgery in patients with sterile necrosis, a more conservative approach to infected necrosis with late intervention, whether endoscopic or surgical, and treatment of biliary pancreatitis. Despite improvements in access to care techniques, diagnostic imaging and interventions, acute pancreatitis continues to be associated with significant morbidity and mortality [8]. In addition, there is no pharmacological therapy available to mitigate the disease and its course, and the management of patients with BP consists of supportive measures, even in cases of concomitant organic failure. [9].

A recent study published in the journal Nature criticizes the fact that mild AP is approached in most studies as selflimited, since it can result in sequelae even after its clinical resolution. Thus, this study points to the importance of systematization in the management of $\mathrm{AP}$ and postulates that primary, secondary and tertiary prevention strategies need to be employed [10]. Severe cases of AP involving necrosis with suspected infection adopt a traditional management mechanism: open necrosectomy, so it is possible to completely remove the infected necrotic tissue. However, this invasive approach is associated with high rates of complications (34 to $95 \%$ ) and death (11 to $39 \%$ ) and with a long-term risk of pancreatic insufficiency. Based on the concept of prevention, but aimed at reducing the risk of mortality in a later phase of acute BP, less invasive techniques, including percutaneous drainage [11] drenagem endoscópica (transgástrica) [12] and minimally invasive retroperitoneal necrosectomy, are increasingly common in use [13-15]. These techniques can be performed in an approach called a step-up [16]. In comparison with open necrosectomy, the step-up approach aims to control the source of infection, rather than the complete removal of infected necrotic tissue, thereby reducing inflammation and tissue damage. A study published in 2010 in the New England Journal of Medicine showed the use of the technique in patients who had necrotizing pancreatitis and confirmed or suspected secondary infection, reduced the rate of serious complications or death, as well as long-term complications, use of resources health costs and total costs. With the intensive approach, more than a third of the patients were successfully treated with percutaneous drainage and did not require major abdominal surgery [17].

Taking into account the incidence of AP and the comorbidities associated with the most severe cases [10], this review addresses the minimally invasive strategies used in the management of AP, highlighting the peritoneum as a central tissue in the immune response to these techniques, especially during continuous peritoneal lavage.
"Step up approach" and continuous peritoneal lavage in the context of severe AP

At worst, AP progresses to necrotizing pancreatitis infected with organ failure, which can have a $35 \%$ mortality rate [7]. The management of infected necrotizing pancreatitis has changed dramatically in the past 20 years and continues to evolve with increasing knowledge, new techniques and ongoing research efforts. Choosing the most appropriate treatment strategy is a complex decision that must be multidisciplinary, as it uses techniques that cover the areas of gastroenterology, surgery, radiology and intensive care [18].

Patients with acute necrotizing and / or infected pancreatitis can be treated in several ways, but the decision on how to treat is largely based on the location of the infected collections, extent of the disease, availability of equipment and knowledge of the various techniques. Although it is a heterogeneous disease and the treatment strategies are different for each patient, it has common goals for treatment: reducing SIRS, oxidative stress and preventing organ failure. Usually, the first strategy used for this is the administration of antibiotics [19], which complements the surgical intervention or even avoids the need for it. In the background, the focus is on minimizing the complications of the disease, as well as intervening to treat them [17].

Some studies provide interesting data on the use of minimally invasive interventions in the context of necrotizing pancreatitis. In 2010, the results of the randomized PANTER study, conducted by the Dutch Acute Pancreatitis Study Group, demonstrated several benefits of the step-up approach on open necrosectomy, such as reduced organ failure, perforation, fistula or bleeding. In 2012, a small randomized study (the PENGUIN study) showed a reduced risk of serious complications in the group that underwent endoscopic transgastric drainage versus surgical necrosectomy ( $20 \%$ vs. $80 \%$, respectively)[20].

The Pancreatitis Study Group in Germany conducted a multicenter study between January 2008 and June 2014 with 220 patients and found that only $44 \%$ of patients in the intensive intervention (percutaneous drainage, endoscopic drainage, with or without minimally invasive necrosectomy) had complications compared to $73.3 \%$ of patients in the open necrosectomy group. In addition, mortality was lower, with $10.5 \%$ in the intensive group versus $33.3 \%$ in the open group [21].

The first attempt to use the human peritoneum to dialysate uremic retention solutes was made almost 100 years ago [22]. Peritoneal dialysis (PD) is a successful form of renal replacement therapy, cardiorenal syndrome [23] and also an approach to treat acute necrotizing pancreatitis. The procedure takes place by introducing dialysis fluid into the peritoneal cavity, which remains in circulation for a few hours and then drains. The characteristics of the liquid inserted in the peritoneal cavity also contributes to the success of $\mathrm{PD}$, since it has electrolytes in its composition, exerting an osmotic pressure at the site and enabling the filtering of undesirable metabolites present in the blood [24-26]. Another factor that makes PD successful is

Citation: Serra MB, Barbeiro DF, De Souza HP, César Machado MC (2021) Continue peritoneal lavage in acute pancreatitis: How do peritoneal cells response? Arch 
the presence of the aquaporin-1 molecule, which is expressed constitutively in the endothelial cells that line the peritoneal capillaries. Aquaporin-1 is a member of a family of highly conserved water channels, organized as homotetramers, with each monomer containing a central pore that facilitates the movement of water through lipid membranes [22,27].

Continuous peritoneal lavage (LPC) is structurally similar to peritoneal dialysis, but the lavage fluid introduced into the peritoneal cavity is concomitantly drained by an outlet catheter. PCL was introduced in the treatment of BP based on the theory that the elimination of ascites containing inflammatory cytokines and inflammatory mediators reduces the severity of the disease. These data suggest that an intensive approach based on peritoneal lavage may be beneficial [28].

In the 1980s, several randomized clinical trials were conducted using minimally invasive strategies, but these did not reveal the beneficial effects of peritoneal lavage, just as they questioned this intervention as the main treatment for acute pancreatitis $[5,29,30,31]$. Despite this, there are still reports of the benefits of peritoneal lavage in experimental models of acute pancreatitis and also in the clinical setting [32]. A prospective study compared the effects of percutaneous drainage with continuous peritoneal lavage in patients with severe acute pancreatitis, showing that the two procedures were not different in terms of reducing mortality or major complications resulting from the condition. However, continuous washing had additional advantages as it reduced the incidence of deep vein thrombosis and pancreatic encephalopathy in these patients [33]. A study conducted by Korean researchers evaluated the effects of peritoneal lavage in a sample of 58 patients who had moderate to severe AP. Of these patients, 31 received only conventional treatment (enteral nutrition, gastrointestinal decompression, antibiotics, fluid resuscitation, antacids and analgesics) and 27 received conventional treatment and peritoneal lavage. After evaluating white blood cells, C-reactive protein in the serum, liver, kidney, pancreatic function and mortality, the authors concluded that continuous peritoneal lavage can significantly reduce mortality, as well as complications and length of hospital stay in moderate to high blood pressure [28]. Although the protective effect of lavage is known in the most severe cases of acute pancreatitis, the mechanisms that involve the participation of peritoneal cells in the pathophysiology of the disease have not yet been clarified, nor is the efficacy of peritoneal lavage in earlier stages yet known. of the PA. It is worth mentioning that the involvement of resident peritoneal cells in the longest survival in animal models has also been described in the literature de sepse [34], peritoneal tumor [35] and hepatitis [36], demonstrating their immunological importance in the pathophysiological mechanism of diseases and the possibility of being pharmacological targets in the future. Clinical studies that have shown the beneficial effects of peritoneal lavage only reinforce the need to investigate which are the peritoneal cells involved in the pathophysiology of the disease, such as the cytokines present in that inflammatory environment.

\section{The peritoneum}

The peritoneum is classically defined as a serous membrane that lines the abdominal cavity, containing the liver, pancreas, spleen, most of the gastrointestinal tract and other viscera. Thus, its classification is based on an anatomical approach, which can be renamed in two ways: visceral peritoneum, which lines the viscera; and parietal, which lines the abdominal cavity wall [37]. However, this classification is somewhat reductionist, as it does not take into account the cellular composition of this tissue, as well as its functions and interactions with other tissues and organs.

De Lamballe, in 1829, was the first to highlight the protective functions of the omentum, formed by layers of peritoneum, as a tissue capable of sealing gastrointestinal perforations and protecting against peritonitis. in the abdominal cavity; as early as 1880 , Senn used this knowledge for surgical innovation: he used omental flaps to protect intestinal sutures [38]. Not to mention the mesentery, which is composed of peritoneum, but is presented to us as an independent structure [39].

A recent literature review draws attention to the complex and dynamic relationship of peritoneal content in the pathophysiology of diseases, as well as the study of its physiology, since most research has focused only on clinical aspects of peritoneal lavage, while the approach of molecular and cellular mechanisms that orchestrate these changes still remain unclear [40]. Still in this review, the authors resume the discussion for some important functions of the peritoneum already addressed, among them, the participation in primitive intestinal embiogenesis [39], cell transport [37] physiological barrier, immunological induction, modulation and inhibition, tissue repair and healing [37,41] protection against tumor adhesion and spread $[42,43]$ e cell migration $[37,44]$.

A small amount of liquid (between 5 and $100 \mathrm{~mL}$ in humans) circulates inside the cavity, which is described as derived from blood ultrafiltration containing immune elements of the complement system, as immunoglobulins, antimicrobial peptides, defensins, immune cells (macrophages, $\mathrm{B}$ cells and $\mathrm{T}$, NK, dendritic and eosinophil cells), mast cells and mesothelial cells [45-50], functioning as a physiological barrier against infection. The presence of a high number of macrophages (around 60\%) and B lymphocytes (about 50\%) residing in the peritoneal cavity (PerC) makes this a preferred site for the collection of these cells [51]. Macrophages are dynamic cells that differentiate into macrophages classically (M1), or alternatively (M2) activated with specific and phenotypic properties, under the influence of signals from the local microenvironment and that are metabolically differentiated [52]. However, in the case of peritoneal macrophages, it is necessary to be careful with this classification, since there is a very high dynamism and plasticity of these cells according to the stimulus in which they are exposed [51]. The literature mentions a majority population of peritoneal macrophages that do not fit in the M1 and M2 classification, as these macrophages have a unique transcription factor (GATA 6) and can behave as much as the classic Macrophage (M1), performing phagocytosis and releasing inflammatory cytokines, as $\mathrm{M} 2$, acting in a more restorative way and producing $\mathrm{IL}-10$, protecting against inflammation [53-55]. These resident peritoneal macrophages have been referred to as the large peritoneal macrophage (large

Citation: Serra MB, Barbeiro DF, De Souza HP, César Machado MC (2021) Continue peritoneal lavage in acute pancreatitis: How do peritoneal cells response? Arch Clin Gastroenterol 7(2): 043-048. DOI: https://dx.doi.org/10.17352/2455-2283.000097 
peritoneal macrophage) (PML), as they are relatively larger than the medullary macrophages present in the circulation. In addition to these, small peritoneal macrophages (SMP) can also be found in the peritoneal cavity, but are physiologically small [56]. These two macrophages can be differentiated by the technique of immunophenotyping and flow cytometry based on their phenotypic markers expressed on the cell membrane. LPMs express high levels of F4 / 80 and CD11b, and low levels of molecules of the main histocompatibility complex (MHCII), appear to originate from embryogenic precursors, and their maintenance in PerC is regulated by the expression of specific transcription factors and derived signals of tissues. On the other hand, SPMs have an F4 / 8olowCD11blow and MHCIIhigh phenotype and are generated from myeloid precursors derived from bone marrow [51,57]. In response to infectious or inflammatory stimuli, the cellular composition of PerC is dramatically altered, where PMS disappear and PMS become the prevalent population along with its precursor, the inflammatory monocyte [54]. Mac-Gata6 KO mice have been shown to develop PMLs in the peritoneal cavity with reduced F4 / 80 expression. In addition, the number of PMS, but not PMS, collected from peritoneal exudate was greatly reduced in MacGata6 KO mice, that is, PMS repopulate PerC in the absence of PML, even though there is no inflammatory or infectious stimulus, but this mechanism has not yet been clarified [58].

PMS seem to be the main source of inflammatory mediators in PerC during infection, while PMS contribute to the production of IgA independent of the lymphoid tissue associated with the intestine and dependent on retinoic acid by peritoneal B1 cells [59]. The cavity is also important for the study of T cells, Natural Killer, dendritic and granulocytes (mainly eosinophils), in addition to B1 cells (which constitute a majority cell population) and conventional B2 cells [57], that can be differentiated as to the expression of CD11b +, an integrin that together with CD18 forms the $\mathrm{CR} 3$ heterodimer. B1 cells are subdivided into B1a and $\mathrm{B} 1 \mathrm{~b}$, which can be distinguished by the superficial expression of CD5. B1 cells $(\mathrm{CD} 11 \mathrm{~b}+)$ are an important source of natural IgM, providing early protection from a variety of pathogens. B1a cells $\left(\mathrm{CD} 11 \mathrm{~b}+\mathrm{CD} 5^{+}\right)$have modulating properties due to their high IL-10 production capacity [60].

\section{Peritoneal cells and acute pancreatitis}

It is known that cells belonging to organs neighboring the pancreas have their phenotype altered in the course of the disease [60]. A work published by XU, et al. (2014), showed that hepatic macrophages modify their phenotype from M1 to M2, through stimulation with $\mathrm{IL}-4$ and Treg cells in vivo and in vitro, promoting a protective effect in mice with severe acute pancreatitis [54]. Another study found that gastric macrophages are responsible for damage to the gastric mucosa when activated during severe acute pancreatitis [61]. In 2009, Gea-Sorlí and Closa [62] published a study that specifically investigated macrophage phenotypes during the progression of a model of acute pancreatitis and SIRS, induced by $5 \%$ sodium taurocholate in rats. The results of this study showed that treatment with IL- 4 and IL-13, M2 profile interleukins, reversed the induction of pancreatitis in vitro, but failed to modulate in vivo activation in peritoneal macrophages.
The effect of peritoneal lavage on the survival of patients with severe acute necrotizing pancreatitis is already known. A study of meta-analysis and systematic review published by $\mathrm{Li}$, et al. (2016)[32] based on a sample of 889 patients from 15 studies concluded that peritoneal lavage significantly decreased mortality in patients with severe acute pancreatitis.

A study group from the USP School of Medicine published a paper on the effects of peritoneal lavage on a model of acute pancreatitis induced by taurocholic acid in rats. In this work, it was demonstrated that peritoneal lavage after severe BP induction reduced the concentration of inflammatory cytokines in the serum of these animals (TNF- $\alpha$ and IL-6) and increased IL-10, which is an anti-inflammatory cytokine. In addition, the expression of cyclooxygenase- 2 and inducible nitric oxide synthase in the pancreas was reduced [63]. A work published by Mikami, et al. (2003)64 revealed that peritoneal macrophages are involved in the progression of acute pancreatitis, but as at that time the macrophage subtypes that could be found in PerC had not yet been described, this question remained open. In this work, macrophage depletion was performed by injecting liposome-encapsulated dichloromethylene bisphosphonate (Cl2MBP liposome), and $48 \mathrm{~h}$ after the induction of acute pancreatitis by taurocholic acid (3\%). Among the results obtained are: reduction in the number of neutrophils, concentration of inflammatory cytokines in the peritoneal and serum lavage, volume of ascites and reduction of pulmonary and pancreatic damage.

A study conducted by Liu, et al. (2018) showed that drainage of ascitic fluid (paracentesis) in this type of BP promoted a change in the macrophage phenotype (transition from M1 to M2), significantly reduced histopathological scores and levels of amylase, lipase, tumor necrosis factor- $\alpha$ and interleukin (IL) $-1 \beta, \mathrm{L}-$ selectin, elevated the cytokines IL- 4 and IL-10 and increased the expression of the anti-inflammatory protein Arg- 1 in the pancreas of rats [65].

\section{Conclusion}

Based on these studies, it is possible that there is a correlation between acute pancreatitis and the dynamics of peritoneal cells in the course of the disease, and that the manipulation of this system can be a strategy to be studied in the management of $\mathrm{BP}$, based on minimally interventions. invasive, such as using techniques for cell characterization.

\section{References}

1. Leppäniemi A, Tolonen $M$, Tarasconi A, Segovia-Lohse $H$, Gamberin E, et al. (2019) 2019 WSES guidelines for the management of severe acute pancreatitis. World Journal of Emergency Surgery 14: 1-20. Link: https://bit.ly/2TiN6SV.

2. Xiao AY, Tan ML, Wu LM, Asrani VM, Windsor JA, et al. (2016) Global incidence and mortality of pancreatic diseases: a systematic review, meta-analysis, and meta-regression of population-based cohort studies. Lancet Gastroenterol Hepatol 1: 45-55. Link: https://bit.ly/3cwn31x

3. Glauco frazão flexa ribeiro, g. h. d. s., maylla luanna barbosa martins, eduarda gomes bogea, joycilene garces cantanhede, joana d'arc matos frança de abreu. etiologia e mortalidade por pancreatite aguda: uma revisão sistemática. Arquivos Catarinenses de Medicina 46. 
4. van Santvoort HC, Bakker OJ, Bollen TL, Besselink MG, Ahmed Ali U,. et al. (2011) A conservative and minimally invasive approach to necrotizing pancreatitis improves outcome. Gastroenterology 141: 1254-63. Link: https://bit.ly/3vbtDRF

5. De Waele E, Malbrain M, Spapen HD (2019) How to deal with severe acute pancreatitis in the critically ill. Curr Opin Crit Care 25: 150-156. Link: https://bit.ly/3v51prv

6. Banks PA, Bollen TL, Dervenis C, Gooszen HG, Johnson CD, et al. (2013) Classification of acute pancreatitis--2012: revision of the Atlanta classification and definitions by international consensus. Gut 62: 102-111. Link: h ttps://bit.ly/3isnBJC

7. Werge M, Novovic S, Schmidt PN, Gluud LL (2016) Infection increases mortality in necrotizing pancreatitis: A systematic review and meta-analysis. Pancreatology 16: 698-707. Link: https://bit.ly/3gpmkjW

8. Greenberg JA, Hsu J, Bawazeer M, Marshall J, Friedrich JO, et al. (2016) Clinical practice guideline: management of acute pancreatitis. Can J Surg 59: 128-40. Link: https://bit.ly/354Cf1A

9. Afghani E, Pandol SJ, Shimosegawa T, Sutton R, Wu BU, et al. (2015) Acute Pancreatitis-Progress and Challenges: A Report on an International Symposium. Pancreas 44: 1195-210. Link: https://bit.ly/3ctlb9W

10. Petrov MS, Yadav D (2019) Global epidemiology and holistic prevention of pancreatitis. Nature Reviews Gastroenterology \& Hepatology 16: 175-184. Link: https://bit.ly/2TXIQdd

11. KE L, Li J, Hu P, Wang L, Chen H, et al. (2016) Percutaneous Catheter Drainage in Infected Pancreatitis Necrosis: a Systematic Review. In: (Ed.). Indian J Surg 78: 221-228. Link: https://bit.ly/2TQ3IBP

12. Papachristou GI, Takahashi N, Chahal P, Sarr MG, Baron TH (2007) Perora endoscopic drainage/debridement of walled-off pancreatic necrosis. Ann Surg 245: 943-951. Link: https://bit.ly/2Tavusx

13. Carter CR, Mckay CJ, Imrie CW (2000) Percutaneous necrosectomy and sinus tract endoscopy in the management of infected pancreatic necrosis: an initial experience. Ann Surg 232: 175-180. Link: https://bit.ly/2TKqpaz

14. Van Santvoort H, Besselink MG, Horvath KD, Sinanan MN, Bollen $T L$, et al. (2007) Videoscopic assisted retroperitoneal debridement in infected necrotizing pancreatitis. HPB (Oxford) 9: 156-159. Link: https://bit.ly/2SfHOTz

15. Horvath KD, Kao LS, Ali A, Wherry KL, Pellegrini CA, et al. (2001) Laparoscopic assisted percutaneous drainage of infected pancreatic necrosis. Surg Endosc 15: 677-682. Link: https://bit.ly/3zd1UmK

16. Windsor JA (2007) Minimally invasive pancreatic necrosectomy. Br J Surg 94: 132-133. Link: https://bit.ly/3g9hcRQ

17. Van Santvoort HC, Besselink MG, Bakker OJ, Hofker HS, Boermeester MA et al. (2010) A Step-up Approach or Open Necrosectomy for Necrotizing Pancreatitis. N Engl J Med 362: 1491-1502. Link: https://bit.ly/3g60hjk

18. Sion MK, Davis KA (2019) Step-up approach for the management of pancreatic necrosis: a review of the literature. Trauma Surg Acute Care Open 4: e000308. Link: https://bit.ly/3zpxl8f

19. Moggia E, Koti R, Belgaumkar AP, Fazio F, Pereira SP, et al. (2017) Pharmacological interventions for acute pancreatitis. Cochrane Database Syst Rev 4: Cd011384. Link: https://bit.ly/3zgmwL2

20. Gomatos IP, Halloran CM, Ghaneh P, Raraty MG, Polydoros F, et al. (2016) Outcomes From Minimal Access Retroperitoneal and Open Pancreatic Necrosectomy in 394 Patients With Necrotizing Pancreatitis. Ann Surg 263 992-1001. Link: https://bit.ly/3zgmumo

21. Rasch S, Phillip V, Reichel S, Rau B, Zapf C, et al. (2016) Open Surgical versus Minimal Invasive Necrosectomy of the Pancreas-A Retrospective Multicenter
Analysis of the German Pancreatitis Study Group. PLoS One 11: e0163651. Link: https://bit.ly/3iAjknp

22. Mehrotra R, Devuyst O, Davies SJ, Johnson DW (2016) The Current State of Peritoneal Dialysis. J Am Soc Nephrol 27: 3238-3252. Link: https://bit.ly/3xe6HIU

23. Francois K, Ronco C, Bargman JM (2015) Peritoneal Dialysis for Chronic Congestive Heart Failure. Blood Purif 40: 45-52. Link: https://bit.ly/3zga4e9

24. Labato MA (2000) Peritoneal dialysis in emergency and critical care medicine. Clin Tech Small Anim Pract 15: 126-135. Link: https://bit.ly/3pE5WQy

25. LI Q, Zhu B, Zhu X, Piao C, Cui W, et al. (2016) Treatment of necrotizing acute pancreatitis with peritoneal lavage and dialysis by a new simplified technique insert catheters: One retrospective study. Medicine (Baltimore) 95. Link: https://bit.ly/3ivXIsg

26. Lankisch PG, Koop H, Winckler K, Schmidt H (1979) Continuous peritonea dialysis as treatment of acute experimental pancreatitis in the rat. II. Analysis of its beneficial effect. Dig Dis Sci 24: 117-122. Link: https://bit.ly/2TWZxo0

27. Crabtree JH, Chow KM (2017) Peritoneal Dialysis Catheter Insertion. Semin Nephrol 37: 17-29. Link: https://bit.ly/3wa3Vy1

28. Jong NRS, Kim H (2019) Clinical effectiveness of continuous peritoneal lavage in moderately severe to severe acute pancreatitis. Muller Journal of Medical Sciences and Research 10: 21-25. Link: https://bit.ly/2TjMigD

29. Cooper MJ, Williamson RC, Pollock AV (1982) The role of peritoneal lavage in the prediction and treatment of severe acute pancreatitis. Ann R Coll Surg Eng 64: 422-427. Link: https://bit.ly/3v9rMN9

30. Mayer AD, McMahon MJ, Corfield AP, Cooper MJ, Williamson RC, et al. (1985) Controlled clinical trial of peritoneal lavage for the treatment of severe acute pancreatitis. N Engl J Med 312: 399-404. Link: https://bit.ly/3vjeyxz

31. Therapeutic Peritoneal-Lavage In Patients With Severe Acute-Pancreatitis. Gut 25: A579-A579.

32. LI Z, Xia C, Zhang L, Zhang Y, Liu Z, et al. (2016) Peritoneal Lavage for Severe Acute Pancreatitis A Meta-analysis and Systematic Review. Pancreas 45: 806813. Link: https://bit.ly/3g7tkmn

33. He WH, Xion ZJ, Zhu Y, Xia L, Zhu Y, et al. (2019) Percutaneous Drainage Versus Peritoneal Lavage for Pancreatic Ascites in Severe Acute Pancreatitis: A Prospective Randomized Trial. Pancreas 48: 343-349. Link: https://bit.ly/2TMek4G

34. Aziz M, et al. (2017) B-1a Cells Protect Mice from Sepsis: Critical Role of CREB. J Immunol 199: 750-760. Link: http://dx.doi.org/10.4049/jimmunol.1602056.

35. Haro MA, Dyevoich AM, Phipps JP, Haas KM, et al. (2019) Activation of B-1 Cells Promotes Tumor Cell Killing in the Peritoneal Cavity. Cancer Research 79: 159-170. Link: : https://bit.ly/2TXom39

36. Wang J. Kubes PA (2016) Reservoir of Mature Cavity Macrophages that Can Rapidly Invade Visceral Organs to Affect Tissue Repair. Cell 165: 668-678. Link: https://bit.ly/3g7KaS5

37. Van Baal JO, Van de Vijver KK, Nieuwland R, van Noorden CJ, van Driel WJ, et al. (2017) The histophysiology and pathophysiology of the peritoneum. Tissue Cell 49: 95-105. Link: https://bit.ly/3pEFhTJ

38. Liebermann-Meffert D (2000) The greater omentum. Anatomy, embryology, and surgical applications. Surg Clin North Am 80: 275-293. Link: https://bit.ly/3g64GCS

39. Burn SF, HILL RE (2009) Left-right asymmetry in gut development: what happens next? Bioessays 31: 1026-1037. Link: https://bit.ly/3g6B2NE

40. Isaza-restrepo A, Martin-Saavedra JS, Velez-Leal JL, Vargas-Barato F, RiverosDueñas R (2018) The Peritoneum: Beyond the Tissue - A Review. Front Physio 9: 12. Link: https://bit.ly/3pEFuX1

Citation: Serra MB, Barbeiro DF, De Souza HP, César Machado MC (2021) Continue peritoneal lavage in acute pancreatitis: How do peritoneal cells response? Arch Clin Gastroenterol 7(2): 043-048. DOI: https://dx.doi.org/10.17352/2455-2283.000097 
41. Yung S, Chan TM (2012) Pathophysiological changes to the peritoneal membrane during PD-related peritonitis: the role of mesothelial cells. Mediators Inflamm 2012: 484167. Link: https://bit.ly/3xgNMqZ

42. Mutsaers SE (2002) Mesothelial cells: their structure, function and role in serosal repair. Respirology 7: 171-91. Link: https://bit.ly/3plJtBZ

43. Mutsaers SE (2004) The mesothelial cell. Int J Biochem Cell Biol 36: 9-16. Link: https://bit.ly/3572952

44. Wang ZB, LI M, LI JC (2010) Recent advances in the research of lymphatic stomata. Anat Rec (Hoboken) 293: 754-761. Link: https://bit.ly/3xg5dYF

45. Bain CC, Jenkins SJ (2018) The biology of serous cavity macrophages. Cell Immunol 330: 126-135. Link: https://bit.ly/3v8mGRd

46. Ray A, Dittel BN (2010) Isolation of Mouse Peritoneal Cavity Cells. J Vis Exp 35: 2010. Link: https://bit.ly/3glzPkt

47. Clarke AJ, Riffelmacher T, Braas D, Cornall RJ, Simon AK (2018) B1a B cells require autophagy for metabolic homeostasis and self-renewal. Journal of Experimental Medicine 215: 399-413. Link: https://bit.ly/3wniVbS

48. Composto G, Gonzalez D, Bucknum A, Silberman D, Taylor J, et al. (2011) Peritoneal T lymphocyte regulation by macrophages. Immunobiology 216 256-264. Link: https://bit.ly/356EjXe

49. Kobayashi T, Noguchi T, Saito K, Shirasaki F, Kita H, et al. (2018) Eosinophilic Inflammation in Peritoneal Fibrosis Patients Undergoing Peritoneal Dialysis. Contrib Nephrol 196: 1-4. Link: https://bit.ly/3xc6fVC

50. Mccully ML, Madrenas J (2006) Dendritic cells as arbiters of peritoneal immune responses. Perit Dial Int 26: 8-25. Link: https://bit.ly/3cwqTrt

51. Cassado Ados A, D'imperio Lima MR, Bortoluci KR (2015) Revisiting mouse peritoneal macrophages: heterogeneity, development, and function. Front Immunol 6: 225. Link: https://bit.ly/2Sm6QoE .

52. Galvan-pena S, O'neill LA (2014) Metabolic reprograming in macrophage polarization. Front Immunol 5: 420. Link: https://bit.ly/3gr9sJW

53. Cain DW, O'Koren EG, Kan MJ, Womble M, Sempowski GD, et al. (2013) Identification of a tissue-specific, C/EBPbeta-dependent pathway of differentiation for murine peritoneal macrophages. J Immunol 191: 46654675. Link: https://bit.ly/3zioLOk

54. Takenaka E, Van Vo A, Yamashita-Kanemaru Y, Shibuya A, Shibuya K, et al (2018) Selective DNAM-1 expression on small peritoneal macrophages contributes to $\operatorname{CD} 4(+) \mathrm{T}$ cell costimulation. Sci Rep 8: 15180. Link: https://bit.ly/352IQei

55. Gautier EL, Ivanov S, Williams JW, Huang SC, Marcelin G, et al. (2014) Gata6 regulates aspartoacylase expression in resident peritoneal macrophages and controls their survival. J Exp Med 211: 1525-1531. Link: https://bit.ly/3v4I5Mg

56. Cassado Ados A, de Albuquerque JA, Sardinha LR, Buzzo Cde L, Faustino L, et al. (2011) Cellular renewal and improvement of local cell effector activity in peritoneal cavity in response to infectious stimuli. PLoS One 6: e22141. Link: https://bit.ly/3cwcFXo

57. Ghosn EE, Cassado AA, Govoni GR, Fukuhara T, Yang Y, et al. (2010) Two physically, functionally, and developmentally distinct peritoneal macrophage subsets. Proc Natl Acad Sci U S A 107: 568-573. Link: https://bit.ly/2TiSmG9

58. Okabe Y, Medzhitov R (2014) Tissue-specific signals control reversible program of localization and functional polarization of macrophages. Cell 157: 832-844. Link: https://bit.ly/3g7wEy4
59. Wang RX, Colgan SP (2017) Special pro-resolving mediator (SPM) actions in regulating gastrointestinal inflammation and gut mucosal immune responses. Mol Aspects Med 58: 93-101. Link: https://bit.ly/3va0AOi

60. Maseda D, Candando KM, Smith SH, Kalampokis I, Weaver CT, et al. (2013) Peritoneal Cavity Regulatory B Cells (B10 Cells) Modulate IFN- $\gamma+C D 4+T$ Cell Numbers During Colitis Development in Mice. J Immunol 191: 2780-2795. Link: https://bit.ly/3xdptdw

61. Dang SC, Wang H, Zhang JX, Cui L, Jiang DL, et al. (2015) Are gastric mucosa macrophages responsible for gastric injury in acute pancreatitis? World $\mathrm{J}$ Gastroenterol 21: 2651-2657. Link: https://bit.ly/3csukPS

62. Gea-Sorli S, Closa D (2009) In vitro, but not in vivo, reversibility of peritonea macrophages activation during experimental acute pancreatitis. BMC Immunol 10: 42. Link: https://bit.ly/3v7dahb

63. Souza LJ, Coelho AM, Sampietre SN, Martins JO, Cunha JE, et al. (2010) AntiInflammatory Effects of Peritoneal Lavage in Acute Pancreatitis. Pancreas 39 : 1180-1184. Link: https://bit.ly/3csQxNB

64. Mikami Y, Takeda K, Shibuya K, Qiu-Feng H, Shimamura H, et al. (2003) Do peritoneal macrophages play an essential role in the progression of acute pancreatitis in rats? Pancreas 27: 253-260. Link: https://bit.ly/2Sf7pAR

65. Liu RH, Wen Y, Sun HY, Liu CY, Zhang YF, et al. (2018) Abdominal paracentesis drainage ameliorates severe acute pancreatitis in rats by regulating the polarization of peritoneal macrophages. World J Gastroenterol 24: 5131-5143. Link: https://bit.ly/2TUnQ62

Discover a bigger Impact and Visibility of your article publication with

\section{Peertechz Publications}

\section{Highlights}

* Signatory publisher of ORCID

* Signatory Publisher of DORA (San Francisco Declaration on Research Assessment)

* Articles archived in worlds' renowned service providers such as Portico, CNKI, AGRIS, TDNet, Base (Bielefeld University Library), CrossRef, Scilit, J-Gate etc.

* Journals indexed in ICMJE, SHERPA/ROMEO, Google Scholar etc.

* OAI-PMH (Open Archives Initiative Protocol for Metadata Harvesting)

* Dedicated Editorial Board for every journal

* Accurate and rapid peer-review process

* Increased citations of published articles through promotions

* Reduced timeline for article publication

Submit your articles and experience a new surge in publication services (https://www.peertechz.com/submission).

Peertechz journals wishes everlasting success in your every endeavours.

Copyright: @ 2021 Serra MB, et al. This is an open-access article distributed under the terms of the Creative Commons Attribution License, which permits unrestricted use distribution, and r eproduction in any medium, provided the original author and source are credited.

Citation: Serra MB, Barbeiro DF, De Souza HP, César Machado MC (2021) Continue peritoneal lavage in acute pancreatitis: How do peritoneal cells response? Arch Clin Gastroenterol 7(2): 043-048. DOI: https://dx.doi.org/10.17352/2455-2283.000097 